\title{
The optimization of desulfurization conditions by response surface methodology
}

\author{
Shui-Quan Chen, Chao-Cheng Zhao ${ }^{\dagger}$, Meng Zang and Xiao-Xiao Wang \\ Environmental and Safety Engineering, China University of Petroleum, \\ Qingdao, Shandong, China \\ tE-mail: zhaochch@upc.edu.cn \\ www.upc.edu.cn
}

\begin{abstract}
Dibenzothiophene and its derivatives are components of high-sulfur crude oil, and these sulfides would reduce the oil quality and increase sulfur dioxide emissions when burned, which will decline environmental quality. Compared with the traditional desulfurization method, biodesulfurization has many advantages, but how to improve the biological desulfurization efficiency has been an important issue. In this study, culture conditions and desulfurization conditions were optimized by response surface methodology (RSM) to improve the biological desulfurization efficiency. Based on the single-factor experiments, Plackeet-Burman method (PB) was used to determine the main factors which would influence the efficiency of desulfurization. And the three main factors were temperature, $\mathrm{pH}$ and DBT concentration. Response surface optimization experiments show that when temperature was $29.70^{\circ} \mathrm{C}$, initial $\mathrm{pH}$ was 7.43 , and DBT concentration was $105.47 \mathrm{mg} / \mathrm{L}$, the desulfurization rate would be maximum, theoretical maximum degradation rate were $72.32 \%$, and actual degradation rate were $74 \%$. The interaction between the three key factors was significant, the influence degree was DBT concentration $>\mathrm{pH}>$ temperature. This study provides a method to improve the biological desulfurization efficiency by optimizing culture conditions and desulfurization conditions.
\end{abstract}

Keywords: Biodesulfurization; Dibenzothiophene; Response Surface Methodology.

\section{Introduction}

The sulfides in petroleum, such as dibenzothiophene and its derivatives, will reduce the quality of the oil product, and the combustion products will cause serious pollution to the air[1-4]. In view of this, more and more strict oil sulfur standards have been promulgated and implemented, and now refining industry in China is facing an unprecedented severe challenge to reduce the sulfur content of oil. The traditional desulfurization methods are chemical and physical methods. Sulfur-containing heterocyclic aromatic hydrocarbons existed in petroleum are difficult to be removed by conventional methods, but it can be done with biodesulfurization technology[5-8]. Bio desulfurization is a method to

\footnotetext{
† Work partially supported by "the Fundamental Research Funds for the Central Universities"
} 
selectively convert the sulfur content of oil into water soluble sulfur compounds by microbial enzymes, and then through the oil and water separation method, the purpose of oil desulfurization will be achieved. Compared with catalytic desulfurization, bio desulfurization has many advantages, such as less investment, lower operating cost, cleaner and easier removal of thiophene compounds and so on, but it also has the following shortcomings at the same time, for example, flexibility is low, the process is not easy to control, and more stringent requirements are needed, due to the growth of microorganisms requires a certain condition[9-12]. It is a very important thing to create a good growth condition for the microorganism to improve the desulfurization efficiency. In this study, we provide a method, response surface methodology (RSM), to improve the biological desulfurization efficiency by optimizing culture conditions and desulfurization conditions.

\section{Materials and Methods}

\subsection{Materials}

Dibenzothiophene (DBT) were purchased from SIGMA, America.

\subsection{Bacteria strain and cultivation}

Rhodopseudomonas sp. Strain AS-21 which can remove dibenzothiophene (DBT) effectively was used in this study. DBT-acetone solution: DBT was dissolved in acetone $(10 / \mathrm{L})$ and thenstored in the refrigerator. Sulfur-free medium (BSM): $2.44 \mathrm{~g}$ of $\mathrm{KH}_{2} \mathrm{PO}_{4}, 14.03 \mathrm{~g}$ of $\mathrm{Na}_{2} \mathrm{HPO}_{4} \cdot 12 \mathrm{H}_{2} \mathrm{O}, 0.36 \mathrm{~g}$ of $\mathrm{MgCl}_{2} \cdot 6 \mathrm{H}_{2} \mathrm{O}, 1 \mathrm{mg}$ of $\mathrm{CaCl}_{2} \cdot 2 \mathrm{H}_{2} \mathrm{O}, 1 \mathrm{mg}$ of $\mathrm{FeCl}_{3} \cdot 6 \mathrm{H}_{2} \mathrm{O}, 4 \mathrm{mg}$ of $\mathrm{MnCl}_{2} \cdot 4 \mathrm{H}_{2} \mathrm{O}$, $10 \mathrm{~g}$ of glycerin, $2.00 \mathrm{~g}$ of $\mathrm{NH}_{4} \mathrm{Cl}$, dissolved in 11 distilled water. Liquid selective medium (BSDM): 100mL BSM adding an appropriate amount of DBT-acetone solution as the sole source of sulfur.

\subsection{Analytical methods}

Dibenzothiophene was analyzed by GC, and Cell mass concentration was detected by UV (OD620).

\subsection{Detection of DBT content in culture medium}

Bacteria were cultured in BSDM (containing 100mg/L DBT) for 2 days. $25 \mathrm{ml}$ of bacterial culture solution was taken to separating funnel, and then it was acidified to $\mathrm{pH} 2$ by the addition of $\mathrm{HCl}$. The remaining dibenzothiophene in the culture solution was extracted with equal volume of n-hexane. Collect n-hexane 
extract after 20min. The extract was centrifuged for $10 \mathrm{~min}(10000 \mathrm{r} / \mathrm{min})$. The obtained n-hexane extract was used for gas chromatography analysis.

\subsection{Detection of cell mass concentration}

Bacterial suspension has characteristic absorption peak at $620 \mathrm{~nm}$. After determination of the absorbance of the bacterial suspension in OD620, cell mass concentration in culture medium could be obtained by the standard curve of the relationship between the absorbance and the mass concentration of the strains.

\section{Results and Discussion}

\subsection{Plackeet-Burman (PB) experiment}

Plackeet-Burman experiment was based on the single factor experiment which was done before this study. The results of the single factor experiment were shown in Table 1.

Table 1. The results of the single factor experiment.

\begin{tabular}{|c|c|c|c|c|c|}
\hline $\begin{array}{l}\text { carbon } \\
\text { sources }\end{array}$ & $\begin{array}{c}\text { glycerol } \\
\text { concentration }\end{array}$ & $\begin{array}{c}\text { nitrogen } \\
\text { sources }\end{array}$ & $\begin{array}{c}\mathrm{NH}_{4} \mathrm{Cl} \\
\text { concentration }\end{array}$ & temperature $\mathrm{pH}$ & $\begin{array}{c}\text { DBT } \\
\text { concentration }\end{array}$ \\
\hline glycerol & $10 \mathrm{~g} / \mathrm{L}$ & $\mathrm{NH} 4 \mathrm{Cl}$ & $2 \mathrm{~g} / \mathrm{L}$ & $30^{\circ} \mathrm{C}$ & $100 \mathrm{mg} / \mathrm{L}$ \\
\hline
\end{tabular}

Based on the results of the single factor experiment, experimental design table using Plackeet-Burman method (PB) could be made. The experimental results could be analyzed by Design-Expert software, shown in Table 2.

Table 2. Partial regression coefficients and significant impact factor analysis.

\begin{tabular}{cccccc}
\hline factor & $\begin{array}{c}\text { Regression } \\
\text { coefficients }\end{array}$ & $\begin{array}{c}\text { Standard } \\
\text { error }\end{array}$ & $\mathrm{E}(\mathrm{x} 1)$ & $\begin{array}{c}\text { Sum of } \\
\text { squares }\end{array}$ & $\begin{array}{c}\text { Contribution } \\
\text { value }\end{array}$ \\
\hline A- temperature & -0.046 & 0.021 & -0.095 & 0.032 & 12.46 \\
$\begin{array}{c}\text { B-pH } \\
\text { C- glycerol }\end{array}$ & $-3.80 \mathrm{E}-02$ & 0.021 & -0.072 & 0.015 & 8.85 \\
$\begin{array}{c}\text { concentration } \\
\text { D- } \mathrm{NH}_{4} \mathrm{Cl} \\
\text { concentration }\end{array}$ & 0.014 & 0.021 & 0.025 & $1.88 \mathrm{E}-03$ & 1.08 \\
$\begin{array}{c}\text { E- DBT } \\
\text { concentration }\end{array}$ & $-1.50 \mathrm{E}-03$ & 0.021 & $-5.00 \mathrm{E}-03$ & $7.50 \mathrm{E}-05$ & 0.04 \\
\hline
\end{tabular}

The three factors, which showed the maximum contribution value, are temperature, $\mathrm{pH}$ and DBT concentration. According to the Plackeet-Burman method (PB), these three factors were the main factors affecting desulfurization efficiency. The $\mathrm{E}(\mathrm{x} 1)$ value shows that, based on the single factor experiment, desulfurization efficiency can be improved when temperature and $\mathrm{pH}$ were reduced appropriately or the DBT concentration was increased. 


\subsection{Response surface optimization experiment}

The response surface optimization experiment was designed based on the PB experiment. Temperature, $\mathrm{pH}$ and DBT concentration were the independent variables, the desulfurization rate was the dependent variable. The results were shown in Table 3.

Table 3. BBD experimental designs and results

\begin{tabular}{cccccc}
\hline Run & $\mathrm{T}\left({ }^{\circ} \mathrm{C}\right)$ & $\mathrm{pH}$ & DBT $(\mathrm{mg} / \mathrm{L})$ & $\begin{array}{c}\text { Desulphurizatio } \\
\text { n rate }(\%)\end{array}$ & cell mass $(\mathrm{g} / \mathrm{L})$ \\
\hline 1 & 25.00 & 8.00 & 120.00 & 42.23 & 1.593 \\
2 & 30.00 & 7.50 & 100.00 & 71.67 & 2.351 \\
3 & 35.00 & 8.00 & 120.00 & 41.78 & 1.697 \\
4 & 30.00 & 7.50 & 133.64 & 68.01 & 2.176 \\
5 & 30.00 & 7.50 & 100.00 & 73.18 & 2.373 \\
6 & 30.00 & 7.50 & 66.36 & 52.56 & 2.053 \\
7 & 25.00 & 8.00 & 80.00 & 39.12 & 1.428 \\
8 & 38.41 & 7.50 & 100.00 & 31.79 & 0.458 \\
9 & 30.00 & 7.50 & 100.00 & 74.87 & 2.348 \\
10 & 30.00 & 8.34 & 100.00 & 47.78 & 1.636 \\
11 & 30.00 & 7.50 & 100.00 & 72.13 & 2.381 \\
12 & 25.00 & 7.00 & 120.00 & 44.29 & 1.744 \\
13 & 35.00 & 8.00 & 80.00 & 38.21 & 1.482 \\
14 & 30.00 & 7.50 & 100.00 & 70.57 & 2.219 \\
15 & 35.00 & 7.00 & 80.00 & 46.01 & 1.652 \\
16 & 30.00 & 6.66 & 100.00 & 49.55 & 1.979 \\
17 & 35.00 & 7.00 & 120.00 & 45.78 & 1.798 \\
18 & 25.00 & 7.00 & 80.00 & 43.78 & 1.789 \\
19 & 21.59 & 7.50 & 100.00 & 38.69 & 1.37 \\
20 & 30.00 & 7.50 & 100.00 & 68.95 & 2.068 \\
\hline
\end{tabular}

The results were analyzed by Design-Expert software. The model was determined according to the results of variance analysis by selecting different models. The results of the analysis of variance are shown in Table 4 and Table 5. 
Table 4. ANOVA for response surface quadratic model.

\begin{tabular}{ccccccr}
\hline Source & $\begin{array}{c}\text { Sum of } \\
\text { Squares }\end{array}$ & df & $\begin{array}{c}\text { Mean } \\
\text { Square }\end{array}$ & $\begin{array}{c}\mathrm{F} \\
\text { Value }\end{array}$ & $\begin{array}{c}\text { p-value } \\
\text { Prob>F }\end{array}$ & \\
\hline Model & 3851.26 & 9 & 427.92 & 29.25 & $<0.0001$ & significant \\
$\mathrm{X}_{1}$-Temperature & 6.26 & 1 & 6.26 & 0.43 & 0.5278 & \\
$\mathrm{X}_{2}$-pH & 33.84 & 1 & 33.84 & 2.31 & 0.1592 & \\
$\mathrm{X}_{3}$-DBT & 79.47 & 1 & 79.47 & 5.43 & 0.0420 & \\
concentration & 3.23 & 1 & 3.23 & 0.22 & 0.6487 & \\
$\mathrm{X}_{1} \mathrm{X}_{2}$ & $9.800 \mathrm{E}-003$ & 1 & $9.800 \mathrm{E}-003$ & $6.700 \mathrm{E}$ & \multirow{2}{*}{0.9799} & \\
$\mathrm{X}_{1} \mathrm{X}_{3}$ & 5.12 & 1 & 5.12 & 0.35 & 0.5672 & \\
$\mathrm{X}_{2} \mathrm{X}_{3}$ & 2743.21 & 1 & 2743.21 & 187.53 & $<0.0001$ & \\
$\mathrm{X}_{1}{ }^{2}$ & 1180.41 & 1 & 1180.41 & 80.70 & $<0.0001$ & \\
$\mathrm{X}_{2}{ }^{2}$ & 351.98 & 1 & 351.98 & 24.06 & 0.0006 & \\
$\mathrm{X}_{3}{ }^{2}$ & 146.28 & 10 & 14.63 & & & not \\
Residual & 125.24 & 5 & 25.05 & 5.95 & 0.1362 & significant \\
Lack of Fit & 21.04 & 5 & 4.21 & & & \\
Pure Error & 3997.54 & 19 & & & & \\
Cor Total & & & & & & \\
\hline
\end{tabular}

Table 5. Analysis Table

\begin{tabular}{cccc}
\hline R-Squared & Adi-Squared & Pred-Squar & Adeq Precisior \\
\hline 0.9634 & 0.9305 & N/A & 14.85 \\
\hline
\end{tabular}

Table 4 indicate that this model is significant (Model "Prob $>F$ " less than 0.0500). The "Lack of Fit F-value" of 5.95 and "Lack of Fit "Prob $>F$ " of 0.1362 imply that the Lack of Fit is not significantly relative to the pure error. All these indicate that this model can be used.

"Adeq Precision" measures the signal to noise ratio. In this model, the "Adeq Precision" of 14.85 indicates a high reliability. This model can be used to predict the desulfurization efficiency of strain AS-21.

The influence degree was DBT concentration> $\mathrm{pH}>$ temperature based on "p-value".

A Second-degree polynomials equation was obtained using Design-Expert software, shown in Eq. (1).

$$
\begin{aligned}
Y= & 72.02-0.68 X_{1}-1.57 X_{2}+2.41 X_{3}-0.63 X_{1} X_{2} \\
& -0.035 X_{1} X_{3}+0.80 X_{2} X_{3}-13.80 X_{1}^{2}-9.05 X_{2}^{2}-4.94 X_{3}^{2}
\end{aligned}
$$

Where $\mathrm{Y}$ represents the desulfurization rate, $\mathrm{X}_{1}, \mathrm{X}_{2}$ and $\mathrm{X}_{3}$ represent temperature, $\mathrm{pH}$ and DBT concentration respectively.

Optimization solutions were obtained under the condition of the maximum response value, according to this model. Results show that when temperature was $29.70^{\circ} \mathrm{C}$, initial $\mathrm{pH}$ was 7.43 , and DBT concentration was $105.47 \mathrm{mg} / \mathrm{L}$, the desulfurization rate would be maximum and theoretical maximum degradation rate would be $72.32 \%$. Experiments were carried out under the above optimal 
desulfurization conditions and growth conditions, and the actual degradation rate was $74 \%$, which was close to the theoretical value.

\section{Conclusions}

This study provide a method to improve the biological desulfurization efficiency by optimizing culture conditions and desulfurization conditions. Response surface optimization experiments show that the desulfurization rate would be maximum when temperature was $29.70^{\circ} \mathrm{C}$, initial $\mathrm{pH}$ was 7.43 , and DBT concentration was $105.47 \mathrm{mg} / \mathrm{L}$. Theoretical maximum degradation rate were $72.32 \%$, and actual degradation rate were $74 \%$ under these conditions.

\section{References}

1. Ahmad, A., et al., Desulfurization of thianthrene by a Gordonia sp. IITR100. Biotechnology Letters, 2014. 36(11): p. 2209-2214.

2. Ahmad, A., et al., Preferential desulfurization of dibenzyl sulfide by an isolated Gordonia sp IITR100. 3 Biotech, 2015. 5(3): p. 237-243.

3. Bahuguna, A., et al., Desulfurization of dibenzothiophene (DBT) by a novel strain Lysinibacillus sphaericus DMT-7 isolated from diesel contaminated soil. Journal of Environmental Sciences-China, 2011. 23(6): p. 975-982.

4. Bhatia, S. and D.K. Sharma, Biodesulfurization of dibenzothiophene, its alkylated derivatives and crude oil by a newly isolated strain Pantoea agglomerans D23W3. Biochemical Engineering Journal, 2010. 50(3): p. 104-109.

5. Buzanello, E.B., et al., A novel Bacillus pumilus-related strain from tropical landfarm soil is capable of rapid dibenzothiophene degradation and biodesulfurization. Bmc Microbiology, 2014. 14.

6. Chauhan, A.K., et al., Biodesulfurization of benzonaphthothiophene by an isolated Gordonia sp IITR100. International Biodeterioration \& Biodegradation, 2015. 104: p. 105-111.

7. Ma, C.-Q., et al., Methods for the preparation of a biodesulfurization biocatalyst using Rhodococcus sp. Chemosphere, 2006. 65(1): p. 165-169.

8. Monticello, D.J., Biodesulfurization and the upgrading of petroleum distillates. Current opinion in biotechnology, 2000. 11(6): p. 540-6.

9. Paixao, S.M., et al., Screening of novel yeast inulinases and further application to bioprocesses. New Biotechnology, 2013. 30(6): p. 598-606.

10. Rashtchi, M., et al., Analysis of biodesulfurization of model oil system by the bacterium, strain RIPI-22. Biochemical Engineering Journal, 2006. 29(3): p. 169-173. 
11. Suleiman, M., A. Bassi, and A. Margaritis, Biodesulfurization of refractory organic sulfur compounds in fossil fuels. Biotechnology Advances, 2007. 25(6): p. 570-596.

12. Yu, B., et al., Deep desulfurization of diesel oil and crude oils by a newly isolated Rhodococcus erythropolis strain. Applied and Environmental Microbiology, 2006. 72(1): p. 54-58. 